\title{
Modelling Rainfed Pearl Millet Yield Sensitivity to Abiotic Stresses in Semi-Arid Central Tanzania, Eastern Africa
}

\author{
Festo Richard Silungwe ${ }^{1,2, *(D)}$, Frieder Graef ${ }^{2}\left(\mathbb{D}\right.$, Sonoko Dorothea Bellingrath-Kimura ${ }^{1,2}(\mathbb{D}$, \\ Emmanuel A Chilagane ${ }^{3}$, Siza Donald Tumbo ${ }^{4}$, Fredrick Cassian Kahimba ${ }^{4}$ and \\ Marcos Alberto Lana ${ }^{5}$ \\ 1 Leibniz Center for Agricultural Landscape Research (ZALF), Eberswalder Straße, 84, \\ 15374 Müncheberg, Germany \\ 2 Humboldt Universität zu Berlin, Faculty of Life Sciences, Unter den Linden 6, 10099 Berlin, Germany \\ 3 Tanzania Agricultural Research Institute, Uyole Research Centre, P.O. Box 400, Mbeya, Tanzania \\ 4 Sokoine University of Agriculture, P.O. Box 3003, CHUO KIKUU, Morogoro 3003, Tanzania \\ 5 Crop Production Ecology, Swedish University of Agricultural Sciences, Ulls väg 16, 75007 Uppsala, Sweden \\ * Correspondence: festo.richard@zalf.de; Tel.: +30-255767786036
}

Received: 4 July 2019; Accepted: 7 August 2019; Published: 10 August 2019

check for updates

\begin{abstract}
Drought and heat-tolerant crops, such as Pearl millet (Pennisetum glaucum), are priority crops for fighting hunger in semi-arid regions. Assessing its performance under future climate scenarios is critical for determining its resilience and sustainability. Field experiments were conducted over two consecutive seasons (2015/2016 and 2016/2017) to determine the yield responses of the crop (pearl millet variety "Okoa") to microdose fertilizer application in a semi-arid region of Tanzania. Data from the experiment were used to calibrate and validate the DSSAT model (CERES Millet). Subsequently, the model evaluated synthetic climate change scenarios for temperature increments and precipitation changes based on historic observations (2010-2018). Temperature increases of +0.5 to $+3.0^{\circ} \mathrm{C}$ (from baseline), under non-fertilized (NF) and fertilizer microdose (MD) conditions were used to evaluate nine planting dates of pearl millet from early ( 5 December) to late planting (25 February), based on increments of 10 days. The planting date with the highest yields was subjected to 49 synthetic scenarios of climate change for temperature increments and precipitation changes (of $-30 \%$ up to $+30 \%$ from baseline) to simulate yield responses. Results show that the model reproduced the phenology and yield, indicating a very good performance. Model simulations indicate that temperature increases negatively affected yields for all planting dates under NF and MD. Early and late planting windows were more negatively affected than the normal planting window, implying that temperature increases reduced the length of effective planting window for achieving high yields in both NF and MD. Farmers must adjust their planting timing, while the timely availability of seeds and fertilizer is critical. Precipitation increases had a positive effect on yields under all tested temperature increments, but Okoa cultivar only has steady yield increases up to a maximum of $1.5^{\circ} \mathrm{C}$, beyond which yields decline. This informs the need for further breeding or testing of other cultivars that are more heat tolerant. However, under MD, the temperature increments and precipitation change scenarios are higher than under NF, indicating a high potential of yield improvement under MD, especially with precipitation increases. Further investigation should focus on other cropping strategies such as the use of in-field rainwater harvesting and heat-tolerant cultivars to mitigate the effects of temperature increase and change in precipitation on pearl millet yield.
\end{abstract}

Keywords: Pearl millet; DSSAT-CERES Millet; planting dates; climate change; microdose 


\section{Introduction}

Food security is a major concern for many developing countries [1-4]. With large populations of food-insecure families living in the semi-arid region of Sub-Saharan Africa (SSA), the reliance on rainfed agriculture with limited inputs as a major source of food and the driver of their economy [5-7] is worsening the problem. In this region, food availability is dictated by how good the rains are to support agriculture production $[7,8]$. Together with poor soil fertility and drought, rainfall variability poses a significant threat to food production for many households in the area $[5,9-11]$. Irrigation bears high potential in promoting crop yields constrained by rainfall variability challenges [12]. However, its access is a major limiting factor in many SSA countries. In Tanzania, for instance, irrigation is used on less than one percent of the total potential area for irrigation, which is 29.4 million ha [13]. The promotion of infield rainwater harvesting practices such as the use of tied ridges [9], pits [14] and basins [15], as well as the use of micro dams [16,17], is resulting in these practices receiving attention as alternatives for limited access to formal large-scale irrigation. In addition, cultivating drought-tolerant crops, such as pearl millet, and paying close attention to the timing of its planting, is crucial for attaining higher yields [18-20]. The potential of pearl millets to fight hunger is high in semi-arid SSA since it is among the major cereal in the region $[9,21,22]$. Reducing the gap between its potential and actual yields is necessary, but it requires continuous efforts in testing suitable management practices that fit the conditions of its production area. The recommended high inputs rates for synthetic fertilizers in the semi-arid region of SSA (i.e., $80 \mathrm{~kg} \mathrm{~N} \mathrm{ha}^{-1}$ and $40 \mathrm{~kg} \mathrm{P} \mathrm{ha}^{-1}$ for full rate, levels used in semi-arid Tanzania [23]) are commonly unaffordable for many smallholder farmers. Consequently, smallholder low income farmers are mostly affected by low crop production caused by limited access and ability to purchase sufficient inputs before the growing season as technically advised. Instead, to improve production, the use of fertilizer microdosing - the application of small quantities of fertilizer at the time of planting or as top dressing three to four weeks after emergence [24]—is recommended for low income farmers in SSA [21,22,25]. Additional threats of current and future abiotic stresses to crop production must be investigated for specific locations [26,27]. Although temperature increases are limited to $+1.5^{\circ} \mathrm{C}$ according to the Paris Agreement [28] or $+2.0^{\circ} \mathrm{C}$, which is found to be a high risk temperature for SSA, in the case of non-adaptation [29], it is necessary to prepare for possible coping and adaptation strategies using local data by performing the required assessments.

Integrating adaptation strategies and crop modelling approaches provides a robust opportunity to evaluate current and future trends, as well as constraints, for agricultural production. The Decision Support System for Agro-technological Transfer (DSSAT) is a highly-ranked crop model capable of simulating different cropping strategies in semi-arid agro-climatic regions [30,31]. DSSAT models (calibrated and validated) are frequently used to assess the sensitivity of different crops to abiotic stresses $[26,27]$ and to evaluate crop management strategies for current weather conditions and future scenarios $[18,32]$. However, to our understanding, the DSSAT CERES Millet model is not yet calibrated and evaluated in the East African region (EA). Such studies are largely concentrated in West Africa. Examples of these studies include the assessment of impacts of 1.5 versus $2.0^{\circ} \mathrm{C}$ on yields of maize, pearl millet and sorghum [32], determining optimum planting dates for pearl millet for contrasting environments [33], determining the combined effects of nutrient fertilization management and climatic variability on yields of pearl millet [34], and assessing climate change impacts on the productivity of pearl millet [35]. The lack of such studies in semi-arid EA limits the opportunities of preparedness for risks associated with pearl millet production. Consequently, farmers in these areas, who mainly depend on pearl millet as their main staple food crop, are experiencing the loss of harvests and increased food shortages due to annual declines in production [36]. Further, there is limited information on this region regarding the production sustainability of pearl millet under climate change scenarios evaluating temperature increases and precipitation changes. Our main objective in this study is to evaluate yield sensitivities to abiotic stress for a pearl millet crop (Pennisetum glaucum (L.), "Okoa" cultivar, produced under non-fertilized conditions and with the microdosing fertilizer application within the EA context. The specific objectives are (1) to calibrate and validate the DSSAT-CERES Millet model under rainfed 
conditions; (2) to evaluate the sensitivity of pearl millet cultivation to increased temperature (of 0 to $+3.0^{\circ} \mathrm{C}$ increments) using nine different planting dates; (3) to evaluate the responses of pearl millet to the effects of the combined scenarios of temperature increments and change in precipitation using best planting date.

\section{Materials and Methods}

\subsection{Description of the Study Area}

The study area was Idifu village in the Chamwino district of the Dodoma region which is in the semi-arid agro climatic zone of central Tanzania (Figure 1), between latitude $4^{\circ} 7^{\prime \prime}$ and $7^{\circ} 21^{\prime \prime}$ south of the equator and longitudes $36^{\circ} 43^{\prime \prime}$ and $35^{\circ} 5^{\prime \prime}$ east of Greenwich. The area recorded a mean annual precipitation of $481 \pm 183 \mathrm{~mm}$ and an average temperature of $24^{\circ} \mathrm{C}$ for the 9-year period of 2010 to 2018 [37] (Figure 2). Experiments comprised the main experimental plots for collecting data for calibration validation and farmers' baby plots scattered in the village to mimic the experiments as a means of inducing adoption [37]. Soils in the village are mainly sandy, with low total nitrogen and soil organic matter (Table 1). With respect to classification by World Reference Base (WRB) Soil Groups (Table 1), soils at the experimental site are classified as Haplic Acrisols. The features of soils are white/reddish, sandy, loose, high infiltration rate, low moisture retention, and least fertility. The description of the method and analysis used to identify the physical and chemical properties of the soil profile is provided in Table 1 is found in the thesis "Improvement of innovation testing in a research for development framework based on soil information" [38]. The Idifu site represents semi-arid areas with very low annual average yields of pearl millet $\left(<0.5\right.$ tons. $\left.\mathrm{ha}^{-1}\right)$ despite the crop being the main staple food. In addition, farmers in the village cultivate pearl millet "Okoa" TSPM9018 released in 1994 (Pennisetum glaucum (L.) R.Br.) [39] predominantly under rainfed conditions, occupying over 70\% of its land yearly [40]. The level of poverty and hunger is very high in Idifu village [41] due to a high dependency on rainfed agriculture which produces low yields yearly and losses of harvest caused by low rainfall with high variability, limited inputs capacity and inadequate crop management [37].

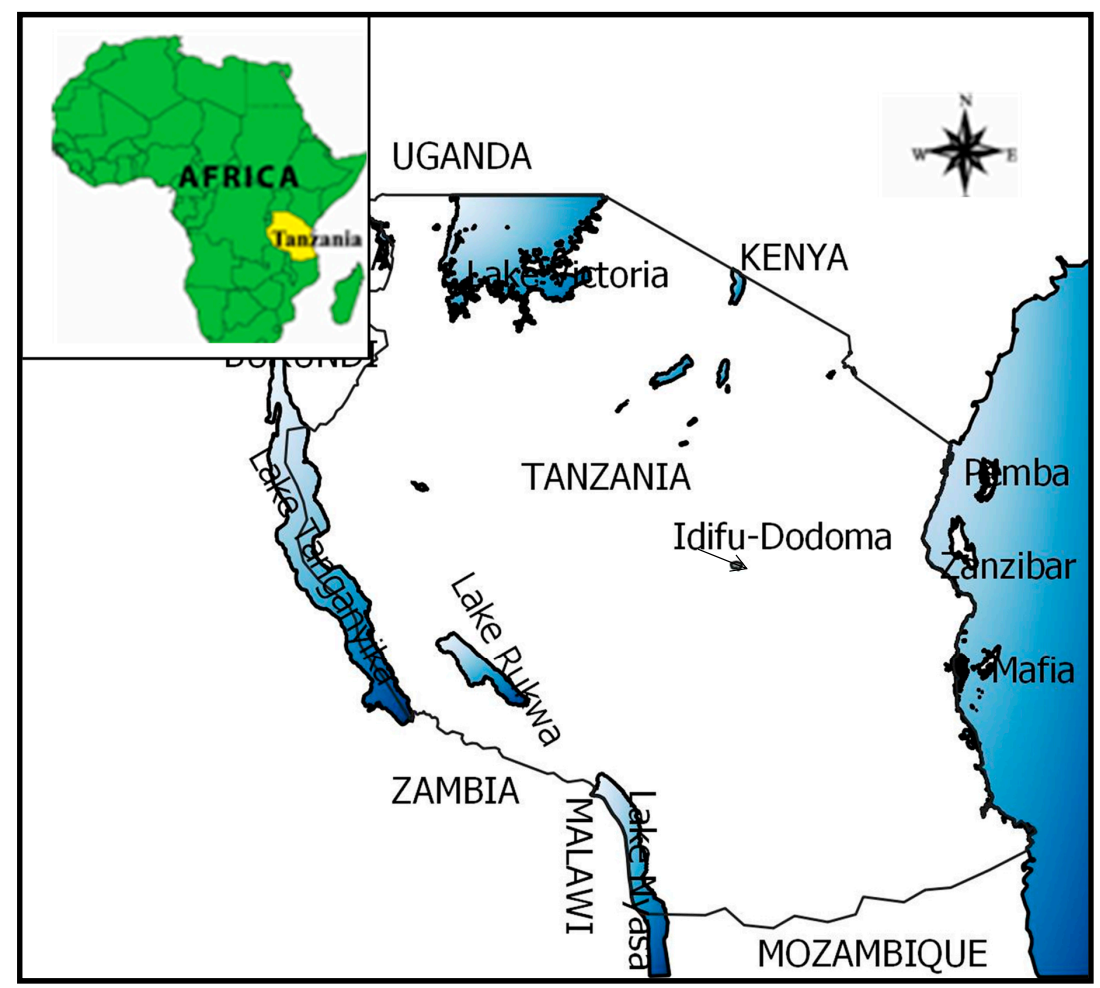

Figure 1. Location of the study site map (Source: Modified from $[30,31]$ ). 
Table 1. Physical and chemical properties of soils at experimental site.

\begin{tabular}{|c|c|c|c|c|c|c|c|}
\hline \multicolumn{8}{|c|}{$\begin{array}{c}\text { Site Name: Idifu, Dodoma, Tanzania } \\
\text { Type: Haplic Acrisol Loamic } \\
\text { Coordinates (WGS84) EPSG 4326: Long } 35^{\circ} 59^{\prime} 10.32^{\prime \prime} \text { E, Lat. } 6^{\circ} 26^{\prime} 26.88^{\prime \prime} \mathrm{S}\end{array}$} \\
\hline \multicolumn{8}{|c|}{ Physical Properties } \\
\hline \multirow[t]{2}{*}{ Horizon } & BD & Depth & Color & & EC & $\mathrm{pH}\left(\mathrm{H}_{2} \mathrm{O}\right)$ & \\
\hline & {$\left[\mathrm{kg} \mathrm{dm}^{-3}\right]$} & {$[\mathrm{cm}]$} & (Munsell) & & {$\left[\mu S \mathrm{~cm}^{-1}\right]$} & - & \\
\hline Ap1 & 1.619 & 4 & $10 y r 3-3$ & & 51.2 & 5.935 & \\
\hline Ap2 & 1.650 & 20 & $10 y r 4-3$ & & 61.1 & 5.570 & \\
\hline $\mathrm{Bt}$ & 1.589 & 42 & $10 y r 5-6$ & & 37.5 & 4.950 & \\
\hline $\mathrm{Bg}$ & 1.616 & $>35$ & $10 y r 5-6$ & & 39.4 & 4.845 & \\
\hline \multicolumn{8}{|c|}{ Chemical Characteristics } \\
\hline & P Bray & K Bray & $\mathrm{Ct}$ & Corg & Humus & $\mathrm{Nt}$ & $\mathrm{C} / \mathrm{N}$ \\
\hline & {$\left[\mathrm{mg} \mathrm{kg}^{-1}\right]$} & {$\left[\mathrm{mg} \mathrm{kg}^{-1}\right]$} & {$[\%]$} & {$[\%]$} & [\%] & {$[\%]$} & \\
\hline Ap1 & 24.90 & 63.05 & 0.40 & 0.40 & 0.69 & 0.03 & 15.29 \\
\hline Ap2 & 0.31 & 73.02 & 0.31 & 0.31 & 0.53 & 0.03 & 12.02 \\
\hline $\mathrm{Bt}$ & 0.20 & 27.58 & 0.20 & 0.20 & 0.35 & 0.02 & 12.55 \\
\hline $\mathrm{Bg}$ & 0.69 & 23.54 & 0.20 & 0.20 & 0.34 & 0.02 & 10.13 \\
\hline \multicolumn{8}{|c|}{ Exchangeable Cations } \\
\hline & CEC Pot & CEC Clay & $\mathrm{Na}^{+}$ & $\mathbf{K}^{+}$ & $\mathrm{Ca}^{2+}$ & $\mathrm{Mg}^{2+}$ & BS \\
\hline & $\underset{\left.\mathrm{kg}^{-1}\right]}{[\text { mmolc }}$ & $\begin{array}{c}\text { [cmolc+ } \\
\left.\mathrm{kg}^{-1}\right]\end{array}$ & $\begin{array}{c}\text { [mmolc+ } \\
\left.\mathrm{kg}^{-1}\right]\end{array}$ & $\begin{array}{c}\text { [mmolct } \\
\left.\mathrm{kg}^{-1}\right]\end{array}$ & $\underset{\left.\mathrm{kg}^{-1}\right]}{[\mathrm{mmolc}+}$ & $\underset{\left.\mathrm{kg}^{-1}\right]}{[\mathrm{mmolc}+}$ & {$[\%]$} \\
\hline Ap1 & 22.90 & 14.238 & 0.40 & 3.75 & 5.70 & 1.075 & 47.71 \\
\hline Ap2 & 24.75 & 25.808 & 0.90 & 4.20 & 4.30 & 0.760 & 41.05 \\
\hline $\mathrm{Bt}$ & 55.55 & 21.902 & 1.15 & 2.75 & 3.45 & 0.880 & 14.82 \\
\hline $\mathrm{Bg}$ & 58.70 & 20.619 & 1.20 & 2.75 & 5.60 & 4.300 & 23.60 \\
\hline \multicolumn{8}{|c|}{ Textural Characteristics } \\
\hline & Sand & Silt & Clay & Texture & & & \\
\hline & [\%] & [\%] & [\%] & Texture & & & \\
\hline Ap1 & 87.43 & 6.11 & 5.76 & LS & & & \\
\hline Ap2 & 88.87 & 5.28 & 4.92 & LS & & & \\
\hline $\mathrm{Bt}$ & 72.50 & 6.97 & 19.98 & SCL & & & \\
\hline $\mathrm{Bg}$ & 68.78 & 6.72 & 22.70 & SCL & & & \\
\hline
\end{tabular}

Meaning of abbreviations: The World Geodetic System 1984 (WGS84), European Petroleum Survey Group (EPSG), Bulk Density (BD), Electrical Conductivity (EC), potential of Hydrogen $(\mathrm{pH})$, water $\left(\mathrm{H}_{2} 0\right)$, Phosphorous and Potassium extracted by Bray extractant (P Bray and K Bray respectively), total Carbon (Ct), organic Carbon (Corg), total Nitrogen (Nt), Cation Exchange Capacity (CEC), Sodium, Potassium, Calcium and Magnesium Exchangeable Cations $\left(\mathrm{Na}^{+}, \mathrm{K}^{+}, \mathrm{Ca}^{+}\right.$, and $\mathrm{Mg}^{+}$respectively), sand (S), loam (L) and clay (C).

\subsection{Weather Data}

Weather data for maximum and minimum temperature and solar radiation were obtained from the Dodoma meteorological station, which is located approximately $50 \mathrm{~km}$ from the study site, for the period between 2010 and 2018 (Figure 2). 

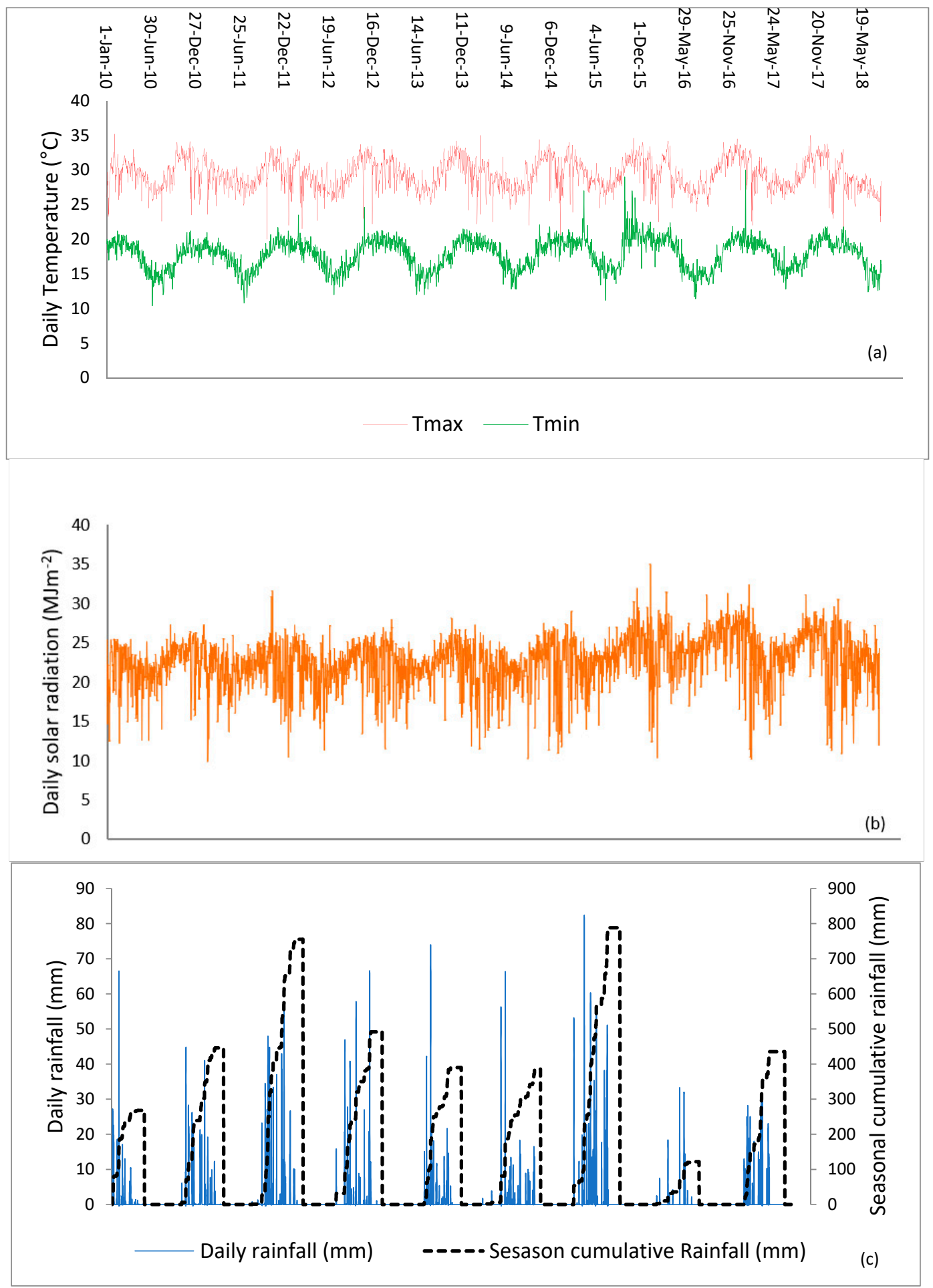

Figure 2. Weather data for the study site (2010-2018) based on daily observation for (a) maximum and minimum temperature $\left({ }^{\circ} \mathrm{C}\right)$; (b) solar radiation $\left(\mathrm{MJm}^{-2}\right)$; and $(\mathbf{c})$ daily rainfall and seasonal cumulative rainfall (mm).

Rainfall data in (Figure 2c) are hybrid of data from the Dodoma Meteorological station (2010-2013) and data collected on site (2014-2018). Daily rainfall data were collected on site using a standard manual rain gauge. The seasonal rainfall for the area is highly variable, with a coefficient of variation (CV) between $10 \%$ and $14 \%$ in a small area of $15 \mathrm{~km}^{2}$ [9]. Additionally, the area is susceptible to severe spatial variabilities in daily rainfall amounts that can exceed a spatial threshold CV of $300 \%[30,31]$. 
For the two seasons, the driest season was 2016/2017 with good rains recorded in 2015/2016 (Figure 2), presenting two contrasting rainfall conditions for rainfed production (a typical rainfall characteristic of semi-arid SSA regions), which was useful for model calibration and validation.

\subsection{Input Data, and Model Calibration and Validation}

The Decision Support System for Agro-technological Transfer (DSSAT 4.7), specifically theCERES Millet model, which is among the components of the DSSAT cropping system model (CSM) [31], is used in the calibration and evaluation of the pearl millet variety "Okoa" TSPM9018 released in 1994 (Pennisetum glaucum (L.) R.Br.) [39]. The input data required for the model are soil, crop, weather (Figure 2), and management data [31]. Input soil data are obtained from the soil profile (Table 1). Crop data are obtained from an experiment lasting two seasons for the pearl millet variety "Okoa". Data for planting dates, plant population, emergence dates, anthesis dates, maturity dates, tops weight and grain yield were recorded. Planting was carried out on 23 December 2015 for season one (SES1) (year 2015/16) and on 10 January 2017 for season two (SES2) (year 2016/17). The planting population was 8 plants $/ \mathrm{m}^{2}$ or 80,000 plants per hectare. Two fertilizers types were applied at two stages as a microdose (MD) and compared to non-fertilized treatment (NF). Fertilizers used for MD were diammonium phosphate (DAP), applied at planting by deep placement and urea applied 21 days after planting by top dressing (Table 2). The treatments NF and MD were replicated three times each in a completely randomized design.

Table 2. Fertilizer rates for treatments used in the experiments.

\begin{tabular}{ccc}
\hline Fertilizer Type/Treatments & NF & MD \\
\hline DAP $\left(\mathrm{kg} \mathrm{ha}^{-1}\right)$ & 0 & 21.7 \\
UREA $\left(\mathrm{kg} \mathrm{ha}^{-1}\right)$ & 0 & 24.1 \\
\hline NF represents non-fertilization practices and FMD represents fertilizer microdose.
\end{tabular}

The model requires crop genetic coefficients of pearl millet to simulate development, growth, and yield, as well as soil processes. The available pearl millet genotype coefficients in the CERES Millet model [31] are calibrated with the DSSAT Generalized Likelihood Uncertainty Estimation (GLUE) program. The GLUE method is well documented on its ability to perform well for different crops [42]. Data from SES1 and SES2 were used for calibration and validation. The calibrated and validated parameters were phenology (days to anthesis and days to physiological maturity) and growth data (total biomass at harvest and grain yield). Eight specific cultivar coefficients were adjusted for Okoa pearl millet cultivar during the calibration process. These were thermal time from seedling emergence to the end of the juvenile phase (degree days above the base temperature of $8^{\circ} \mathrm{C}$ ) during which the plant is not responsive to photoperiod (P1), critical photoperiod, or the longest day length (in hours) at which development occurs at a maximum rate ( $\mathrm{P} 2 \mathrm{O})$, at values greater than $\mathrm{P} 2 \mathrm{O}$, the rate of development is reduced. The extent to which phasic development leading to panicle initiation (expressed in degree days) is delayed for each hour increase in photoperiod above P2O (P2R), thermal time (degree days above a base temperature of $10^{\circ} \mathrm{C}$ ) from beginning of grain filling (3-4 days after flowering) to physiological maturity (P5), scaler for relative leaf size (G1), scaler for partitioning of assimilates to the panicle (head) (G4), phyllochron interval = thermal time (degree days) between successive leaf tip appearance (PHINT), tillering coefficient (GT), equivalent to G1, but on tillers, and potential grain size (G5), in $\mathrm{mg}$.

\subsection{Simulation of Planting Dates, Temperature Increments, Change in Precipitation and Their Interactions}

Nine planting dates spread across three planting windows-early (5 December, 25 December, and 25 December), mid (also referred to as "normal" growing period) (5 January, 15 January, and 25 January), and late (5 February, 15 February, and 25 February) - were used to assess the yield 
stability of pearl millet and its susceptibility to seven levels of temperature increments $\left(0\right.$ to $+3^{\circ} \mathrm{C}$ at $+0.5^{\circ} \mathrm{C}$ increment steps) under $\mathrm{NF}$ and MD. The MD is recommended in literature as an adoptable option for low income farmers in semi-arid SSA as it provides significant yield improvements over NF practices $[21,22,30,43-45]$. The most stable planting date in terms of yield was evaluated for combined scenarios of temperature increments and seven levels of change in precipitation ( -30 to $+30 \%$ at $10 \%$ increment steps). A total of 49 synthetic scenarios of climate change were constructed using the incremental method on historical series of observations (2010-2018). The long-term temperature limit of $1.5^{\circ} \mathrm{C}$, suggested in 2015 in the Paris Agreement [28], and the previous established limit of $2.0^{\circ} \mathrm{C}$, in the case of non-adaptation [29], were compared separately to build upon previous findings.

\subsection{Statistical Evaluation of the Model Performance}

Model performance and validity was statistically evaluated by comparing simulated values against independently measured values, using the relative root mean squared error (RRMSE) and coefficient of residual mass (CRM). The RRMSE (Equation (1)) measures accuracy for continuous variables as it expresses error as a fraction of the average measured value [46]. The model simulation is considered excellent, with RRMSE lower than 10\%, good between 10 and $20 \%$, fair from 20 to $30 \%$, and poor if the RRMSE is greater than $30 \%$. The CRM (Equation (2)) measures the tendency of the model to overestimate or underestimate the measurements [47], with a negative CRM indicating a tendency to overestimate.

$$
\begin{gathered}
\text { RRMSE }=\sqrt{\frac{\sum_{i=1}^{n}\left(P_{i}-O_{i}\right)^{2}}{n}} \times \frac{100}{M} \\
C R M=\frac{\sum_{i=1}^{n} O_{i}-\sum_{i=1}^{n} P_{i}}{\sum_{i=1}^{n} O_{i}}
\end{gathered}
$$

where $n$ is the number of observations, $P_{i}$ is the predicted value, $O_{i}$ is the observed value, and $M$ is the mean of the observed variable. Yield responses for temperature-precipitation interactions were analyzed for the effects of combined scenarios using response surfaces generated by Plotly online tools (Plotly Company, Montreal, QC, Canada) for data analytics and visualization. Yield comparison for simulated climatic scenarios was carried out by performing ANOVA using Tool packs in Microsoft Excel.

\section{Results}

\subsection{Calculation of Genetic Coefficients and Model Validation}

The calibration was completed using SES1 data (2016) and the evaluation was completed using SES2 data (2017) for local environmental conditions (soil, weather) and agronomic management (planting date, fertilization, planting population, and soil management). The Generalized Likelihood Uncertainty Estimation (GLUE) program in DSSAT was used to calibrate the genetic coefficient of the pearl millet Okoa variety. The RRMSE values for model calibration and validation are very good (Table 3), indicating the capability of the model to reproduce both phenology and growth of pearl millet for different seasons. Anthesis occurred within two days of observed dates while maturity occurred within one day of observed dates, thus indicating excellent model performance. In this context, the excellent model performance in evaluating biomass and good performance for grain yield (Table 3) implies that same crop genotype coefficients of pearl millet can be used for further evaluations, i.e., the effects of different climate scenarios and crop management. 
Table 3. Cultivar coefficients and model evaluation for Okoa pearl millet variety.

\begin{tabular}{|c|c|c|c|c|c|c|c|c|}
\hline \multicolumn{9}{|c|}{$\begin{array}{l}\text { Okoa Pearl Millet Cultivar Coefficients Calculated by GLUE Using Field Measurements (Calibration), } \\
\text { Followed by Model Validation Outcomes for Anthesis, Physiological Maturity, Tops Weight and Grain Yield }\end{array}$} \\
\hline P1 & P2O & P2R & P5 & G1 & G4 & PHINT & GT & G5 \\
\hline 271.9 & 11.87 & 126.5 & 251.5 & 1.498 & 1.225 & 43 & 1 & 10 \\
\hline & \multicolumn{4}{|c|}{ Calibration (2016) } & \multicolumn{4}{|c|}{ Validation (2017) } \\
\hline $\begin{array}{l}\text { Variable } \\
\text { Name }\end{array}$ & Observed & Simulated & RRMSE (\%) & CRM (\%) & Observed & Simulated & RRMSE (\%) & CRM (\%) \\
\hline Anthesis day & 71 & 71 & 0.0 & 0.00 & 70 & 68 & 2.0 & 1.45 \\
\hline Maturity day & 100 & 101 & 0.8 & -0.60 & 100 & 101 & 1.2 & -0.20 \\
\hline $\begin{array}{l}\text { Tops weight } \\
\left(\mathrm{kg} \mathrm{DW} \mathrm{ha}^{-1}\right)\end{array}$ & 4198 & 4084 & 7.3 & 2.72 & 4629 & 4582 & 3.5 & 1.02 \\
\hline $\begin{array}{l}\text { Grain Yield } \\
\left(\mathrm{kg} \mathrm{DW} \mathrm{ha}^{-1}\right)\end{array}$ & 1078 & 1037 & 6.4 & 3.84 & 890 & 851 & 11.8 & 4.54 \\
\hline
\end{tabular}

P1 thermal time from seedling emergence to the end of the juvenile phase (degree days above the base temperature of $8{ }^{\circ} \mathrm{C}$ ) during which the plant is not responsive to photoperiod, P2O Critical photoperiod or the longest day length (in hours) at which development occurs at a maximum rate. At values greater than P2O, the rate of development is reduced, P2R Extent to which phasic development leading to panicle initiation (expressed in degree days) is delayed for each hour increase in photoperiod above P2O, P5 Thermal time (degree days above a base temperature of $10^{\circ} \mathrm{C}$ ) from beginning of grain filling (3-4 days after flowering) to physiological maturity, G1 Scaler for relative leaf size, G4 Scaler for partitioning of assimilates to the panicle (head), PHINT phyllochron interval = thermal time (degree days) between successive leaf tip appearance, GT Tillering coefficient, equivalent to G1, but on tillers, G5 Potential grain size, mg. RRMSE (relative root mean square error) measures accuracy for continuous variables and CRM (Coefficient of residual mass) is a measure of the tendency of the model to overestimate or underestimate the measurements (A negative CRM shows a tendency to overestimate). DW means dry weight. GLUE means the Generalized Likelihood Uncertainty Estimation program. RRMSE means the relative root mean squared error. CRM means the coefficient of residual mass.

\subsection{Yield Simulation for Different Temperature Incremental Scenarios and Planting Dates}

The response surfaces unveiled that very early planting before 15 December and late planting after 25 January for NF treatment (Figure 3a) produced the lowest yields. The trend is similar to MD (Figure 3b), with 25 December indicating relatively fewer negative effects on yield when the temperature increase is less than $+0.2^{\circ} \mathrm{C}$. Generally, higher yields are found under MD, whereby on the best planting date (5 January), yields increased with temperature up to $+1.5^{\circ} \mathrm{C}$ (Figure $3 \mathrm{~b}$ ). This implied that the cultivar Okoa is susceptible to heat stress since the yield decreased when temperature increases exceeded $1.5^{\circ} \mathrm{C}$. The effects were great for early planting before 25 December and late planting after 15 January; the latter shows near uniform lowest yields for both NF (Figure 3a) and MD (Figure 3b). The highest yields were approximately $600 \mathrm{~kg} \mathrm{DW} \mathrm{ha}^{-1}$ for NF and approximately $1000 \mathrm{~kg} \mathrm{DW} \mathrm{ha}^{-1}$ for MD, all achieved by planting dates that were around 5 January, in the mid planting window. 

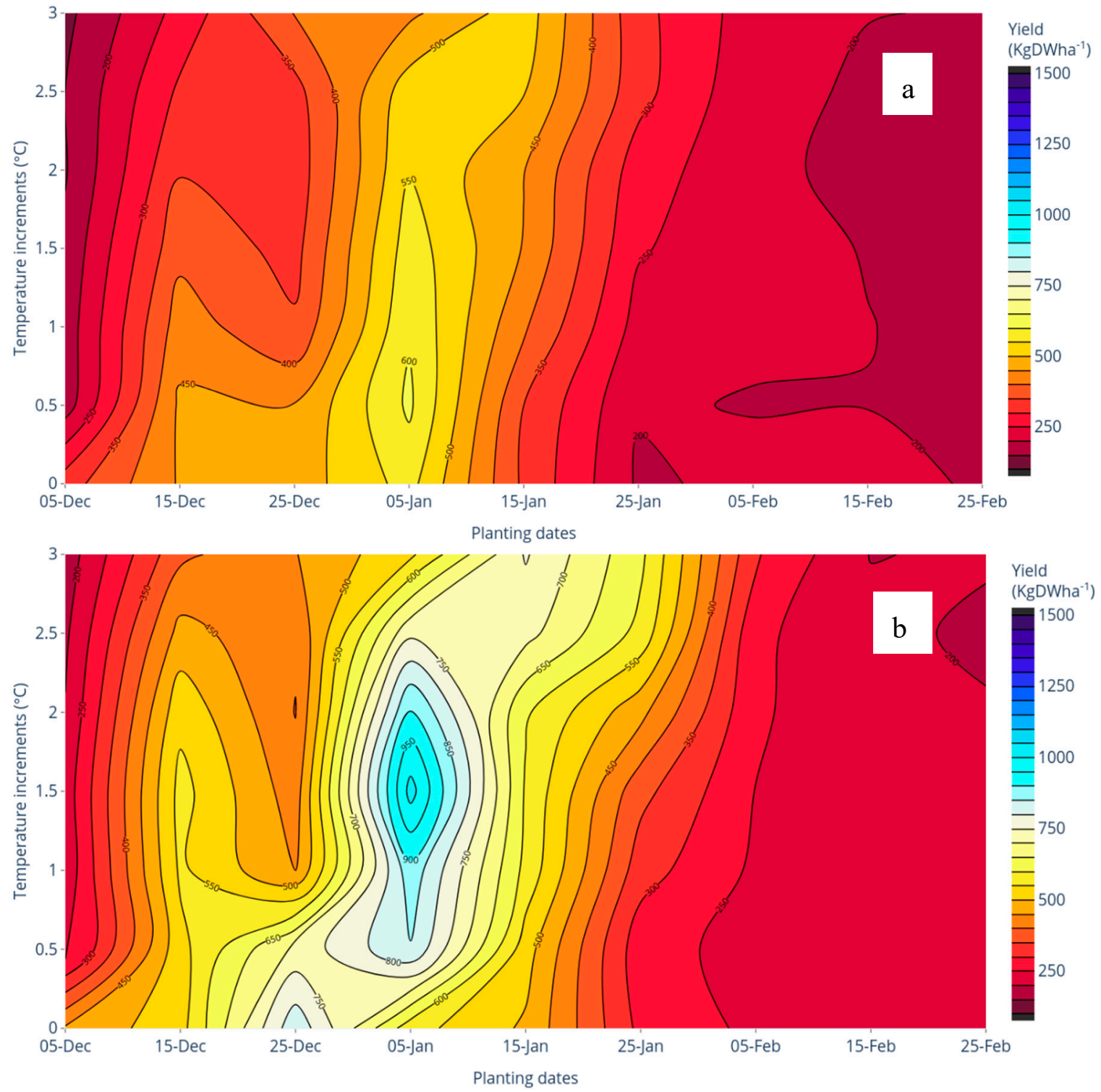

Figure 3. Response surface showing yield change of pearl millet when (a) NF is applied and (b) MD application (Okoa cultivar) under different planting dates (from early and normal, to late planting dates) subjected to scenarios with temperature increments from reference (2010-2018). The closer proximity of isolines indicates a faster reaction to temperature and/or planting dates.

\subsection{Impacts of 1.5 versus $2.0^{\circ} \mathrm{C}$ on Yield for Different Planting Dates}

Both 1.5 and $2.0^{\circ} \mathrm{C}$ increments negatively affect yields for planting events before 5 January when compared to the baseline temperature $\left(0^{\circ} \mathrm{C}\right)$ (Figure 4). However, between these two temperatures $\left(+1.5\right.$ and $\left.+2.0^{\circ} \mathrm{C}\right)$, the yields are not statistically different $(p<0.05)$ across planting dates used under $\mathrm{NF}$ and MD. The effects of two temperature increments when compared to baseline under MD are much more pronounced than NF, but both indicate highest yields when planted on 5 January (Figure 4). Planting events between 5 and 25 January showed positive effects of yields under both NF and MD for both temperature increments, with later planting dates (after 25 January) declining with non-significant yield differences for all temperatures $\left(0{ }^{\circ} \mathrm{C},+1.5^{\circ} \mathrm{C}\right.$ and $+2.0^{\circ} \mathrm{C}$ ) (Figure $4 \mathrm{~b}$ ). For planting dates between 25 January and 25 February, yields are very low with non-significant declining trends for both NF and MD under both temperature scenarios (Figure 4). 

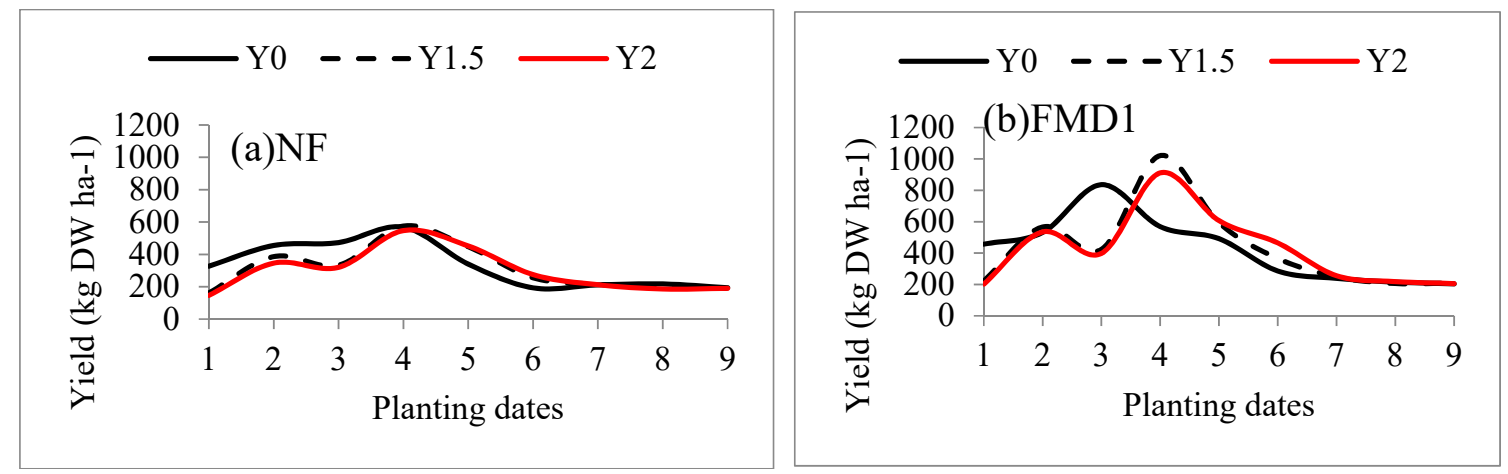

Figure 4. Impacts of 1.5 versus $2.0^{\circ} \mathrm{C}$ on planting dates for the Okoa pearl millet variety yields for (a) NF and (b) MD. Planting dates on $x$ axis refers to (1) 5 December, (2) 15 December, (3) 25 December, (4) 5 January, (5), 15 January, (6) 25 January, (7), 5 February, (8) 15 February, and (9) 25 February. Temperature increments are built from reference period (2010-2018). Y0, Y1.5 and Y2 refer to yields under temperatures of 0 (base), 1.5 , and $2{ }^{\circ} \mathrm{C}$, respectively.

\subsection{Impact of Precipitation Change and Temperature on Yield for Same Planting Date}

The 5 January planting, which showed high stability in yield under temperature increase, was used to assess the scenarios of the combined scenarios of temperature increments and change in precipitation. The increase in precipitation to $+30 \%$ resulted in increased yields in both NF and MD practices (Figure 5). However, pearl millet yields varied with temperature changes under both NF and MD practices, with the later showing greater variability (Figure 5b). Eventually, NF (Figure 5a) showed less yield increase in yield trends than MD (Figure $5 b$ ), similar to trends shown in Figure 3 . Even with $+30 \%$ precipitation increases, the maximum yields recorded were approximately $600 \mathrm{~kg} \mathrm{DW} \mathrm{ha}^{-1}$ under NF, while a maximum yield recorded was approximately $1300 \mathrm{~kg} \mathrm{DW} \mathrm{ha}^{-1}$ under MD.

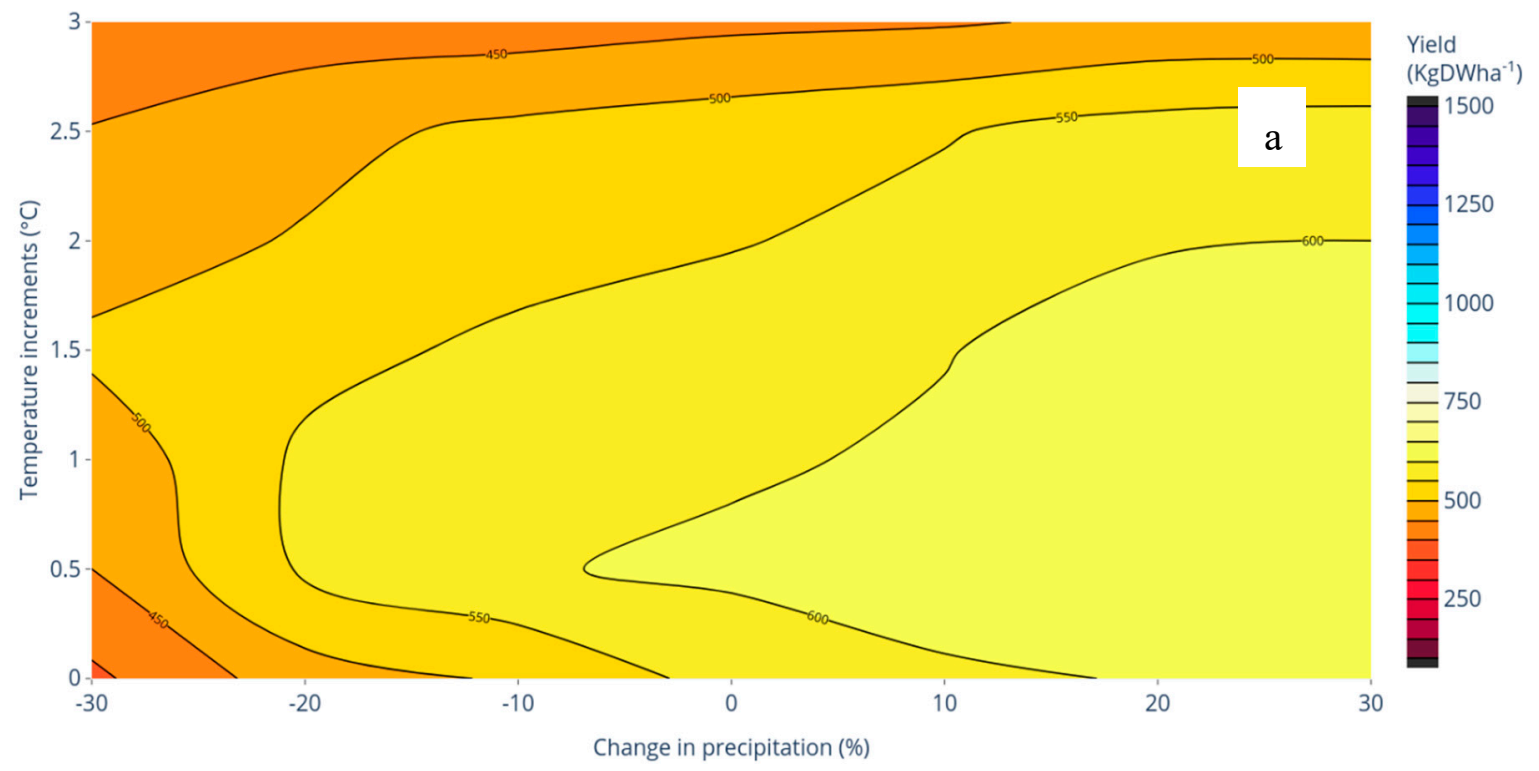

Figure 5. Cont. 


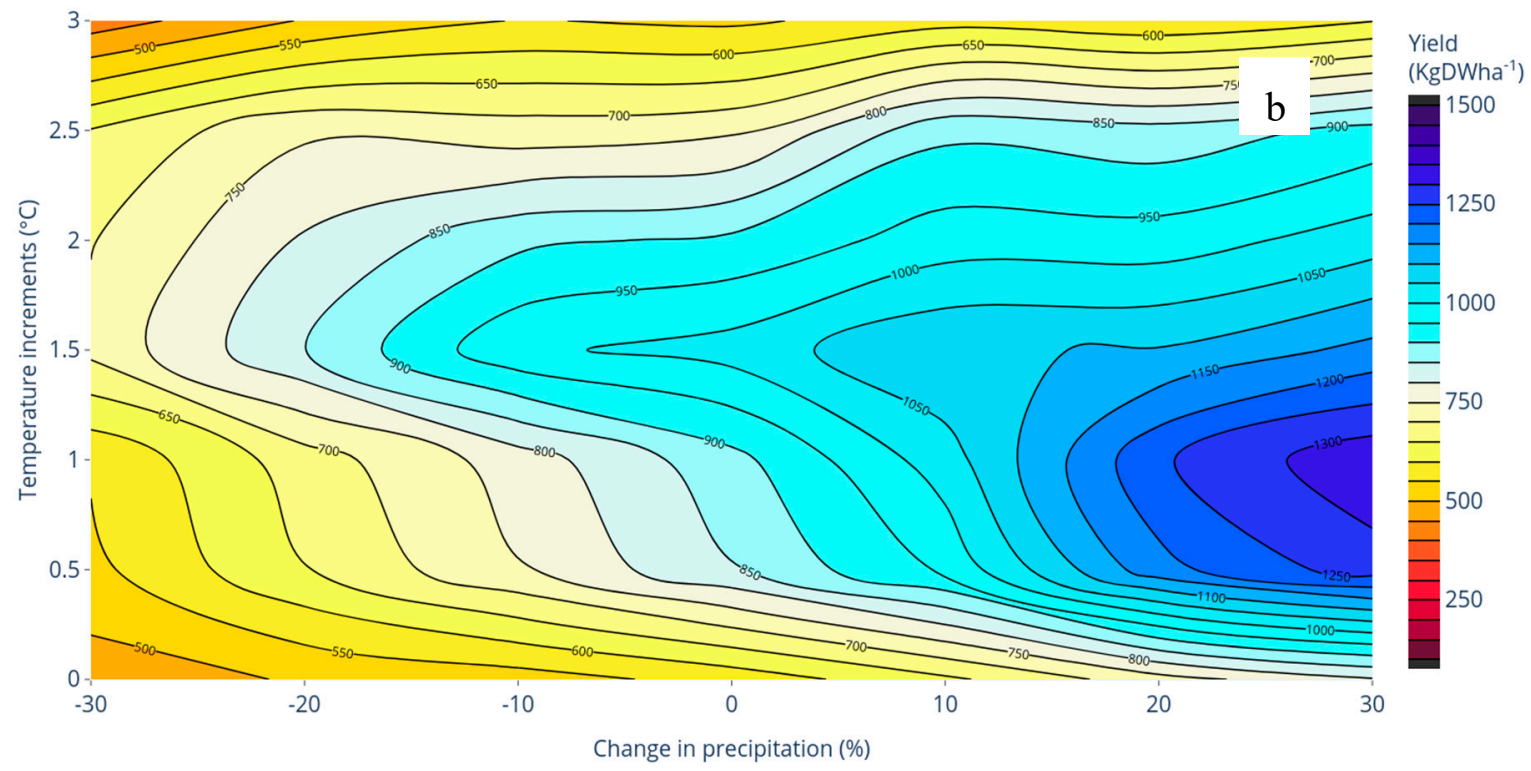

Figure 5. Response surface showing yield change of pearl millet when (a) no fertilizer is applied and (b) with microdose application (Okoa cultivar) under different precipitation and temperature increments scenarios from reference (2010-2018). The closer proximity of isolines indicates faster reactions to temperature and/or precipitation changes.

Temperature increases negatively affected yields; however, the precipitation increase tends to neutralize the effects of temperature (Figure 5). Temperature increases of less than $+1.5^{\circ} \mathrm{C}$ and precipitation increases of over $+20 \%$ resulted into the highest yields of $600 \mathrm{~kg} \mathrm{DW} \mathrm{ha}^{-1}$ for NF (Figure 5a). The variations of yields under NF are low as shown by largely spaced few isolines which indicate low sensitivity of the crop to climatic scenarios. Conversely, pearl millet yields are found to be much more responsive under MD, as indicated by dense isolines (Figure $5 b$ ). In general, there was similarity in the yield trends for NF and MD; for instance, a temperature increase to approximately $+1.5^{\circ} \mathrm{C}$, with a rainfall increase, resulted in consistently increasing yields of pearl millet (Figure 5b); however, beyond this temperature, yields declined gradually. Even with increased precipitation of $+30 \%$, temperature changes between +0.5 and $2.0^{\circ} \mathrm{C}$ can be regarded as the limit for yield levels where there is non-significant yield reduction under MD (Figure $5 b$ ). This can also be stated for yields under NF. Yields at temperatures above $+2.0^{\circ} \mathrm{C}$, even with a $+30 \%$ increase in precipitation, are less than the baseline yield, implying negative responses of the crop to higher temperatures.

\subsection{Yield Impacts of 1.5 versus $2.0^{\circ} \mathrm{C}$ for Different Changes in Precipitation on Same Planting Date}

Pearl millet yield increased with precipitation for all temperature increments (Figure 6). However, under NF, a change in precipitation did not cause yield variations across the $0,+1.5$, and $2{ }^{\circ} \mathrm{C}$ increment levels (Figure 7a). Yield variations were significantly higher $(p<0.05)$ under MD, with +1.5 and $2.0^{\circ} \mathrm{C}$ showing positive improvements in yields (Figure $7 \mathrm{~b}$ ). Relatively higher yields were realized under $+1.5^{\circ} \mathrm{C}$ than either $+2.0^{\circ} \mathrm{C}$ or the baseline (Yo). 

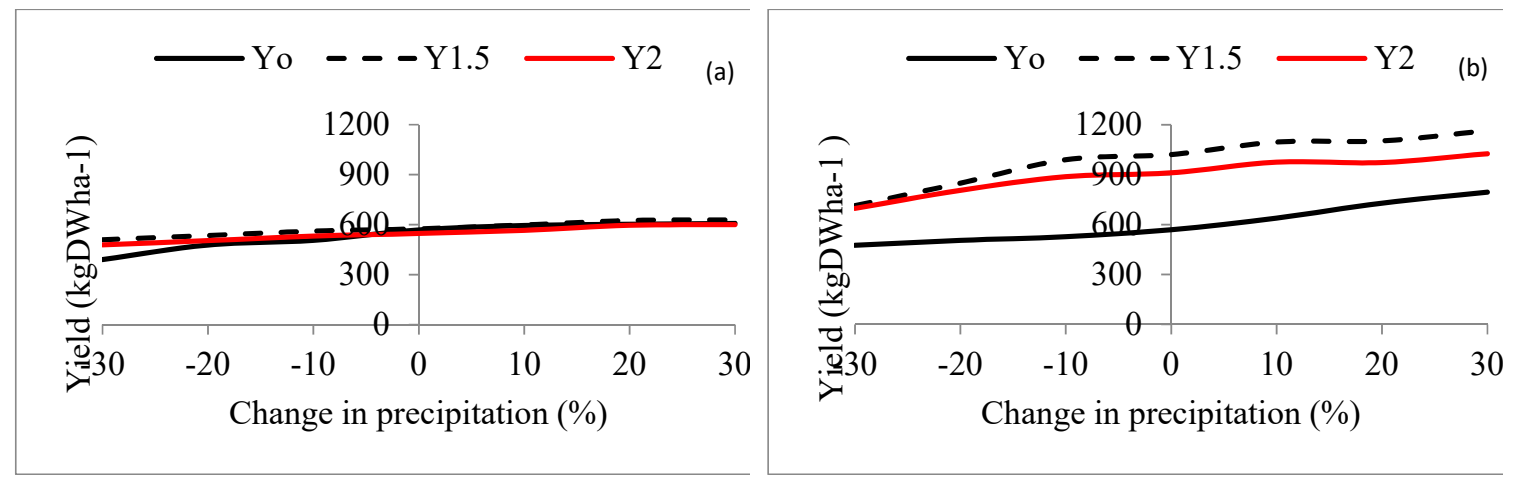

Figure 6. Simulated impacts of $0,1.5$, and $2.0^{\circ} \mathrm{C}$, and change in precipitation on the Okoa pearl millet variety yields for (a) non fertilized and (b) microdose applications. Y0, Y1.5, and Y2 refer to yields for 0 (base), 1.5 , and $2{ }^{\circ} \mathrm{C}$ temperature increments, respectively.
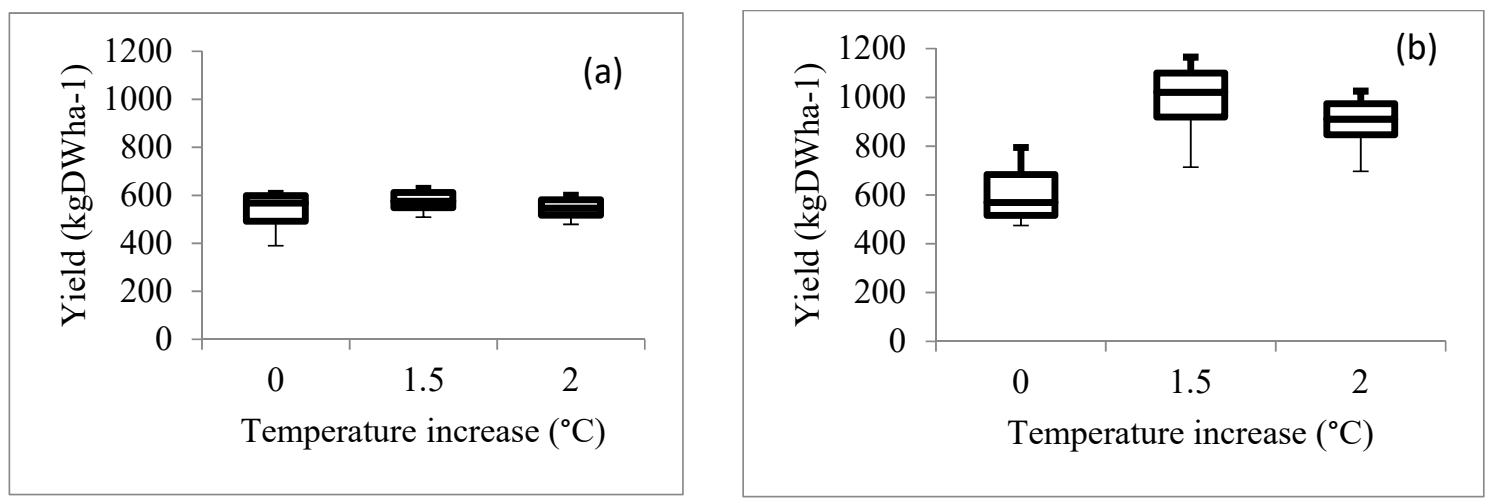

Figure 7. Comparison of yield variations for Okoa pearl millet under (a) non-fertilized and (b) microdose applications due to impacts of $0,1.5$, and $2.0^{\circ} \mathrm{C}$, and changes in precipitation (\%) on variety yields. Planting date is taken to be 5 January for both non fertilized and microdose applications.

\section{Discussion}

Long-term experiments are best for the evaluation of feasible cropping strategies; however, such information is rarely available for crops in SSA, as experiments are typically conducted for two to three seasons. Consequently, combining results from short-term experiments with validated crop models is a less costly, yet reliable, method for deriving sustainable cropping strategy recommendations [43]. In this study, the DSSAT CERES Millet model is calibrated and evaluated for different crop parameters (anthesis days, maturity days, as well as tops weight and grain yield) (Table 3). The model calibration shows excellent performance for all crop parameters. Similarly, the model excellently simulates anthesis, tops weight, and maturity days, while showing a good performance for simulating grain yield during evaluation, as shown by different indicators in Table 3 . The calibration and validation results (Table 3), as backed by indicators suggested by [46] and [47], validate the use of model for analyzing different scenarios.

Model simulations show that the effect of temperature increases caused yield reductions depending on planting date. Late December (25 December) to early January (5 January), when much of the heavy rains are concentrated (Figure 2), emerged as the best planting window under temperature increments of up to $1.5^{\circ} \mathrm{C}$, beyond which the yields declined (Figure 3). This may be associated with cooling effects for the soils, thereby providing the best growth conditions during that period [48] which is around 10 to 30 days after onset of rainy season. Temperature increases reduced the length of planting window for achieving the highest yields for both no fertilized (NF) and with fertilizer microdose (MD) (Figure 3). Both very early and late sowing have disadvantages highly associated with crop water requirement dissatisfaction. While very early planting is susceptible to subsequent dry spells, 
which results in early crop failure before the end of the juvenile stage, and late planting incurs a high chance of limited rainfall during the grain filling. Other crops, such as maize, show a similar response to late planting. A study of optimum planting dates for early maturing maize varieties conducted in Northern Nigeria [49] and a study on hybrid maize cultivars conducted in Brazil [50] are in agreement with our findings. These findings have implications regarding the need for the timely delivery of seeds and fertilizers to farmers as a way to avoid the negative consequences of late planting [51]. A delay of inputs may result in a failure to plant during the optimum planting window, eventually resulting in yield loss. Additionally, as the effects are worse under NF than MD, food-insecure farmers are advised to adopt MD practices in order to reduce the risks of crop loss, since it is affordable as suggested by other findings [44,45].

In Africa, existing studies for the DSSAT CERES Millet model, largely concentrated in the west SSA, evaluate pearl millet crop for +1.5 and $+2{ }^{\circ} \mathrm{C}$ temperature scenarios [29,32]. Aiming to understand the risk associated with the two temperature scenarios [32] and evaluate it in relation to current fertilizer use against intensification. Their recommendations that higher yields will be obtained under intensification are in line with [29], who warn about the production risks associated with non-adopters of crop management strategies. However, since intensification is yet to be achieved, despite being effective, mostly due to limited income for many farmers in the SSA, there is an ongoing shift toward advocating MD [21,22,30,43-45]. The findings of this study (Figure 3) provide a unique understanding of the sustainability, and the associated limitations, of MD for pearl millet farmers. Like [29] and [32], this study shows that non-adopters of MD are more highly affected by 1.5 and $2{ }^{\circ} \mathrm{C}$ scenarios than adopters (Figure 4) in the East African Countries (EAC) context. Although [32] find that the $+2.0^{\circ} \mathrm{C}$ scenario has more negative impacts on yields than the $+1.5^{\circ} \mathrm{C}$ warming scenario, in this study, the two scenarios are not statistically different for pearl millet. However, a slightly higher effect for +2 than $1.5^{\circ} \mathrm{C}$ is observable (Figures $4 \mathrm{~b}$ and $7 \mathrm{~b}$ ). A major reason for the slight differences in our results compared to other studies may be rooted in the different cultivar types and the level of fertilizers used in our study. As stated in Section 2.4, the Okoa pearl millet variety is a localized cultivar that is improved to overcome local environmental challenges.

In the future, not only may temperatures change, but also precipitation [52]. These two important climatic parameters are assessed together in this study in combined scenarios (limiting precipitation between $-30 \%$ and $+30 \%$ change and temperature between 0 and $+3{ }^{\circ} \mathrm{C}$ ) exploring how they affect pearl millet yields. We find that, under the same planting date, precipitation increase affects yields positively under all temperature scenarios for both NF and MD (Figure 5). These results suggests that water availability is the main limiting factor preventing higher yields, even under improved soil fertility, from being achieved $[34,50]$. However, under MD (Figure 5b), the temperature increments and precipitation change scenarios are higher as compared to NF (Figure 5a), where isolines are far spaced, implying a high potential of yield improvement especially with increases in precipitation. Under MD, optimum yields are obtained under temperature increases of $+1.0^{\circ} \mathrm{C}$ and changes in precipitation of $+30 \%$. Thus, in cases of high temporal rainfall variability, as in our case study site, it is advised that farmers adopt infield rainwater harvesting, such as tied ridges $[25,44,45,53-55]$, since they prolonging soil moisture. Although alternatives like providing irrigation may be effective, not only do these require further investigation regarding cost-benefit advantages, but these also may come with insurmountably high initial investment costs [30,31]. We also find that temperatures increases over $+1.5^{\circ} \mathrm{C}$ negatively affect yields under both NF and MD, even with an increase in precipitation of $+30 \%$ (Figure 5), similar to findings by [34]. In agreement with the suggestion of [35], we also suggest that cultivating more heat-tolerant cultivars be considered as a possible coping strategy that improves yield. Further, the results in Figure 5 indicate that the crops that are highly affected by decreased precipitation and increased temperatures are those under NF than those under MD; a result also found by [32]. An increasing trend of yield with increasing precipitation for both NF and MD under both temperature scenarios is observed; however, the increase is greater under MD. Although Faye et al. (2018) urges that long duration variety can barely minimize the risks of yield losses under 
both temperature increments $\left(+1.5^{\circ} \mathrm{C}\right.$ and $\left.+2{ }^{\circ} \mathrm{C}\right)$, we find fewer dates with promising yields (Figure 5); thus, farmers' planting timing is critical for reducing the risk of yield loss, regardless of which cultivar (long or short duration) is chosen.

Timely planting including dry soil planting [18], tied ridges, microdose and scattered fields [9,30], and other strategies of risk minimization in agricultural production found in literature provide useful experience in dealing with rainfed production challenges, but they individually partially address the challenges. An important insight is to combine different strategies together for attaining significant effects. Despite the decades of experiences with rainwater harvesting (tied ridges), heat-tolerant varieties, microdose and timely planting, adoption is still constrained by many aspects such as the availability of financial resources, labor, and environmental constraints [56]. Therefore, strengthening the agro-dealer network is a generally accepted and very well supported recommendation as this will improve accessibility of fertilizer and ensure lower prices through increased competition and information [57]. The precise modalities for achieving this may vary by country context but ensuring a predictable enabling environment for private sector development is the foundation of a vibrant fertilizer market. Expanding contract farming is also likely to yield positive results by providing input credit and reliable output market to farmers. However, further research is recommended on: (a) the basic conditions leading to a suitable development of an agro-dealer network; and (b) examining potential models for such arrangements between farmers, crop buyers, and financial institutions. Farmers' decisions about input use are determined not only by the price or access to fertilizer, but by the profitability of the use of that input generally [57]. An important determinant of profitability is the expected price of the output produced.

Generally, studies focus have increased interests in multiple model inter-comparison to improve model results and robustness [32,58]. Our study is limited to the model inter-comparison component since we only use one model, the DSSAT CERES Millet model. Nevertheless, the strength and usefulness of these findings is clear, as this is the first time, to our knowledge, that the DSSAT CERES Millet model was calibrated and validated using data from a local field experiment in Eastern Africa. The crop genotype coefficients of the Okoa pearl millet variety derived from specific local environmental conditions are now available for further evaluation studies. Furthermore, although MD for pearl millet is heavily advocated in semi-arid SSA, to our understanding, this is the first time it was evaluated in the DSSAT CERES Millet model. Further simulations of management options, such as the influence of tied ridges, effects of irrigation, and regionalization studies of the crop are possible with more robust output, thus helping to improve and sustain millet production.

\section{Conclusions}

The GLUE program in the DSSAT model is effective in calibrating and calculating the genotype coefficients of Okoa pearl millet. A calibrated model is able to reproduce the phenology, total biomass and yields, thus indicating a good performance by the model. Temperature increases affect yields negatively for all planting dates under NF and MD. Early and late planting windows are more negatively affected than the normal planting window, implying that temperature increases reduce the length of the effective planting window for achieving high yields under both NF and FM. Precipitation increases had a positive effect on yields under all the tested temperature increments, but the Okoa cultivar only has stable yield increases up to a maximum of $1.5^{\circ} \mathrm{C}$; thereafter, yields start to decline as the increment in temperature neutralizes the positive effect of water availability. This highlights the need for further breeding or the testing of other cultivars that are more heat tolerant. Still, yields are not significantly different between +1.5 and $+2{ }^{\circ} \mathrm{C}$. A decrease in precipitation negatively affects yield under all temperature scenarios. However, under $\mathrm{MD}$, the temperature increment and precipitation change scenarios are more pronounced as compared to NF, thus indicating a high potential for yield improvements, especially with increasing precipitation if NF shifts to MD. Further investigation should focus on other cropping strategies, such as the use of in-field rainwater harvesting and 
heat-tolerant cultivars that mitigate the effects of temperature increases and precipitation changes on pearl millet yields.

Author Contributions: F.R.S. was involved in conceptualizing the idea, data collection and analysis, experimentation, writing method, implementation, data presentation, writing the original draft paper, and organizing co-authors views. F.G. streamlined the concept, helped in fund acquisition, revised the design of the paper, contributed to its writing, and supervised the whole writing process and administration of the project that financed the work. S.D.B.-K. contributed during conceptualization of the idea, funding acquisition, supported data collection by providing additional resources, and supervision. S.D.T. contributed by revising the idea, assisted in supervising data collection, and provided the reviews to the original draft. F.C.K. contributed during data collection, provided the resource during field work, and supervised the field work. E.A.C. contributed in data collection and analysis. M.A.L. contributed during the conceptualization of the work, supervision of data collection and analysis, revised the method, and an overall review of the paper.

Funding: The research conducted in this study was funded the German Federal Ministry of Agriculture and Food (BMEL) in the form of the Ph.D. program of the Federal Office of Agriculture and Food (BLE).

Acknowledgments: The authors are grateful to the anonymous reviewers for their valuable comments on an earlier version of the manuscript.

Conflicts of Interest: The authors declare no conflict of interest. The funders had no role in the design of the study; in the collection, analyses, or interpretation of data; in the writing of the manuscript, or in the decision to publish the results.

\section{References}

1. Godfray, H.C.J.; Beddington, J.R.; Crute, I.R.; Haddad, L.; Lawrence, D.; Muir, J.F.; Pretty, J.; Robinson, S.; Thomas, S.M.; Toulmin, C. Food security: The challenge of feeding 9 billion people. Science 2010, 327, 812-818. [CrossRef] [PubMed]

2. Hallam, D. International investment in developing country agriculture-Issues and challenges. Food Secur. 2011, 3, 91-98. [CrossRef]

3. Ahmed, M.; Lorica, M.H. Improving developing country food security through aquaculture development-Lessons from Asia. Food Policy 2002, 27, 125-141. [CrossRef]

4. Scherr, S.J. Soil Degradation: A Threat to Developing-Country Food Security by 2020? International Food Policy Research Institute: Montpellier, France, 1999; Volume 27.

5. Cooper, P.J.M.; Dimes, J.; Rao, K.P.C.; Shapiro, B.; Shiferaw, B.; Twomlow, S. Coping better with current climatic variability in the rain-fed farming systems of sub-Saharan Africa: An essential first step in adapting to future climate change? Agric. Ecosyst. Environ. 2008, 126, 24-35. [CrossRef]

6. Rockström, J.; Karlberg, L.; Wani, S.P.; Barron, J.; Hatibu, N.; Oweis, T.; Bruggeman, A.; Farahani, J.; Qiang, Z. Managing water in rainfed agriculture-The need for a paradigm shift. Agric. Water Manag. 2010, 97, 543-550. [CrossRef]

7. Singh, P.; Wani, S.P.; Pathak, P.; Sahrawat, K.L.; Singh, A.K. Increasing crop productivity and effective use of water in rainfed agriculture. Integr. Watershed Manag. Rainfed Agric. 2011, 315-347.

8. Van Ittersum, M.K.; Cassman, K.G.; Grassini, P.; Wolf, J.; Tittonell, P.; Hochman, Z. Yield gap analysis with local to global relevance-A review. Field Crops Res. 2013, 143, 4-17. [CrossRef]

9. Silungwe, F.R.; Graef, F.; Bellingrath-Kimura, S.D.; Tumbo, S.D.; Kahimba, F.C.; Lana, M.A. Analysis of intra and interseasonal rainfall variability and its effects on pearl millet yield in a semiarid agroclimate: Significance of scattered fields and tied ridges. Water 2019, 11, 578. [CrossRef]

10. Thomas, D.S.; Twyman, C.; Osbahr, H.; Hewitson, B. Adaptation to climate change and variability: Farmer responses to intra-seasonal precipitation trends in South Africa. Clim. Change 2007, 83, 301-322. [CrossRef]

11. Müller, C.; Cramer, W.; Hare, W.L.; Lotze-Campen, H. Climate change risks for African agriculture. Proc. Natl. Acad. Sci. USA 2011, 108, 4313-4315. [CrossRef]

12. Cassman, K.G.; Grassini, P. Can there be a green revolution in Sub-Saharan Africa without large expansion of irrigated crop production? Glob. Food Secur. 2013, 2, 203-209. [CrossRef]

13. URT. National Irrigation Policy; Ministry of Water and Irrigation: Dar es Salaam, Tanzania, 2010; p. 70.

14. Schindler, J.; Graef, F.; König, H.J.; Mchau, D.; Saidia, P.; Sieber, S. Sustainability impact assessment to improve food security of smallholders in Tanzania. Environ. Impact Assess. Rev. 2016, 60, 52-63. [CrossRef] 
15. Mupangwa, W.; Love, D.; Twomlow, S. Soil-water conservation and rainwater harvesting strategies in the semi-arid Mzingwane Catchment, Limpopo Basin, Zimbabwe. Phys. Chem. Earth Parts A/B/C 2006, 31, 893-900. [CrossRef]

16. Makurira, H.; Mul, M.L.; Vyagusa, N.F.; Uhlenbrook, S.; Savenije, H.H.G. Evaluation of community-driven smallholder irrigation in dryland South Pare Mountains, Tanzania: A case study of Manoo micro dam. Phys. Chem. Earth Parts A/B/C 2007, 32, 1090-1097. [CrossRef]

17. Gebregziabher, G.; Namara, R.E.; Holden, S. Poverty reduction with irrigation investment: An empirical case study from Tigray, Ethiopia. Agric. Water Manag. 2009, 96, 1837-1843. [CrossRef]

18. Lana, M.A.; Vasconcelos, A.C.F.; Gornott, C.; Schaffert, A.; Bonatti, M.; Volk, J.; Graef, F.; Kersebaum, K.C.; Sieber, S. Is dry soil planting an adaptation strategy for maize cultivation in semi-arid Tanzania? Food Secur. 2018, 10, 897-910. [CrossRef]

19. Nyakudya, I.W.; Stroosnijder, L. Effect of rooting depth, plant density and planting date on maize (Zea mays L.) yield and water use efficiency in semi-arid Zimbabwe: Modelling with AquaCrop. Agric. Water Manag. 2014, 146, 280-296. [CrossRef]

20. Hadebe, S.; Modi, A.; Mabhaudhi, T. Drought tolerance and water use of cereal crops: A focus on sorghum as a food security crop in sub-Saharan Africa. J. Agron. Crop Sci. 2017, 203, 177-191. [CrossRef]

21. Bagayoko, M.; Maman, N.; Palé, S.; Sirifi, S.; Taonda, S.; Traore, S.; Mason, S. Microdose and N and P fertilizer application rates for pearl millet in West Africa. Afr. J. Agric. Res. 2011, 6, 1141-1150.

22. Bielders, C.L.; Gérard, B. Millet response to microdose fertilization in south-western Niger: Effect of antecedent fertility management and environmental factors. Field Crops Res. 2015, 171, 165-175. [CrossRef]

23. Kimaro, A.A.; Timmer, V.R.; Chamshama, S.A.O.; Ngaga, Y.N.; Kimaro, D.A. Competition between maize and pigeonpea in semi-arid Tanzania: Effect on yields and nutrition of crops. Agric. Ecosyst. Environ. 2009, 134, 115-125. [CrossRef]

24. Chataway, R.G.; Doogan, V.J.; Strong, W.M. Fertilizer Microdosing: Boosting Production in Unproductive Lands; ICRISAT: Hajderabad, India, 2009.

25. Habtemariam, L.T.; Mgeni, C.P.; Mutabazi, K.D.; Sieber, S. The farm income and food security implications of adopting fertilizer micro-dosing and tied-ridge technologies under semi-arid environments in central Tanzania. J. Arid Environ. 2019, 166, 60-67. [CrossRef]

26. Corbeels, M.; Chirat, G.; Messad, S.; Thierfelder, C. Performance and sensitivity of the DSSAT crop growth model in simulating maize yield under conservation agriculture. Eur. J. Agron. 2016, 76, 41-53. [CrossRef]

27. Lana, M.A.; Eulenstein, F.; Schlindwein, S.L.; Graef, F.; Sieber, S.; Bittencourt, H.V. Yield stability and lower susceptibility to abiotic stresses of improved open-pollinated and hybrid maize cultivars. Agron. Sustain. Dev. 2017, 37, 30. [CrossRef]

28. United Nations. Adoption of the Paris agreement. In Proceedings of the Conference of the Parties, Geneva, Switzerland, 11 December 2015.

29. Smith, K.; Woodward, A.; Campbell-Lendrum, D.; Chadee, D.; Honda, Y.; Liu, Q.; Olwoch, J.; Revich, B.; Sauerborn, R. Human health: Impacts, adaptation, and co-benefits. In Climate Change 2014: Impacts, Adaptation, and Vulnerability. Part A: Global and Sectoral Aspects. Contribution of Working Group II to the Fifth Assessment Report of the Intergovernmental Panel on Climate Change; Cambridge University Press: Cambridge, UK, 2014.

30. Silungwe, F.R.; Graef, F.; Bellingrath-Kimura, S.D.; Tumbo, S.D.; Kahimba, F.C.; Lana, M.A. Crop upgrading strategies and modelling for rainfed cereals in a semi-arid climate-A review. Water 2018, 10, 356. [CrossRef]

31. Jones, J.W.; Hoogenboom, G.; Porter, C.H.; Boote, K.J.; Batchelor, W.D.; Hunt, L.; Wilkens, P.W.; Singh, U.; Gijsman, A.J.; Ritchie, J.T. The DSSAT cropping system model. Eur. J. Agron. 2003, 18, 235-265. [CrossRef]

32. Faye, B.; Webber, H.; Naab, J.B.; MacCarthy, D.S.; Adam, M.; Ewert, F.; Lamers, J.P.; Schleussner, C.-F.; Ruane, A.; Gessner, U. Impacts of 1.5 versus $2.0 \mathrm{C}$ on cereal yields in the West African Sudan Savanna. Environ. Res. Lett. 2018, 13, 034014. [CrossRef]

33. Soler, C.M.T.; Maman, N.; Zhang, X.; Mason, S.C.; Hoogenboom, G. Determining optimum planting dates for pearl millet for two contrasting environments using a modelling approach. J. Agric. Sci. 2008, 146, 445-459. [CrossRef]

34. Rezaei, E.E.; Gaiser, T.; Siebert, S.; Sultan, B.; Ewert, F. Combined impacts of climate and nutrient fertilization on yields of pearl millet in Niger. Eur. J. Agron. 2014, 55, 77-88. [CrossRef] 
35. Singh, P.; Boote, K.; Kadiyala, M.; Nedumaran, S.; Gupta, S.; Srinivas, K.; Bantilan, M. An assessment of yield gains under climate change due to genetic modification of pearl millet. Sci. Total Environ. 2017, 601, 1226-1237. [CrossRef]

36. Mkonda, M.; He, X. Yields of the major food crops: Implications to food security and policy in Tanzania's semi-arid agro-ecological zone. Sustainability 2017, 9, 1490. [CrossRef]

37. Silungwe, F.R.; Graef, F.; Bellingrath-Kimura, S.D.; Tumbo, S.D.; Kahimba, F.C.; Lana, M.A. The management strategies of pearl millet farmers to cope with seasonal rainfall variability in a semi-arid agroclimate. Agronomy 2019, 9, 400. [CrossRef]

38. Reinhardt, N. Improvement of innovation testing in a research for development framework based on soil information. Ph.D. Thesis, submitted to the Faculty of Agricultural Sciences, Universität Hohenheim, Hohenheim, Germany, 2018; pp. 70-83.

39. Monyo, E.; Mgonja, M.; Ngereza, J.; Rohrbach, D. Adoption of improved sorghum and pearl millet varieties in Tanzania. Int. Sorghum Millets Newslett. 2002, 43, 12-14.

40. Kahimba, F.C.; Mutabazi, K.D.; Tumbo, S.D.; Masuki, K.F.; Mbungu, W.B. Adoption and scaling-up of conservation agriculture in Tanzania: Case of Arusha and Dodoma regions. Nat. Res. 2014, 5, 161-176. [CrossRef]

41. Mgeni, C.; Müller, K.; Sieber, S. Sunflower value chain enhancements for the rural economy in Tanzania: A village computable general equilibrium-CGE approach. Sustainability 2019, 11, 75. [CrossRef]

42. Jones, J.W.; He, J.; Boote, K.J.; Wilkens, P.; Porter, C.; Hu, Z. Estimating DSSAT cropping system cultivar-specific parameters using Bayesian techniques. Methods Introd. Syst. Models Agric. Res. 2011, 365-394. [CrossRef]

43. Tovihoudji, P.G.; Akponikpè, I.P.; Agbossou, E.K.; Bielders, C.L. Using the DSSAT model to support decision making regarding fertilizer microdosing for maize production in the sub-humid region of Benin. Front. Environ. Sci. 2019, 7, 13. [CrossRef]

44. Graef, H.; Kiobia, D.; Saidia, P.; Kahimba, F.; Graef, F.; Eichler-Löbermann, B. Combined effects of biochar and fertilizer application on maize production in dependence on the cultivation method in a sub-humid climate. Commun. Soil Sci. Plant Anal. 2018, 49, 2905-2917. [CrossRef]

45. Saidia, P.S.; Rweyemamu, C.L.; Asch, F.; Semoka, J.M.; Kimaro, A.A.; Germer, J.; Graef, F.; Lagweni, P.; Kahimba, F.; Chilagane, E.A. Effects of nitrogen and phosphorus micro-doses on maize growth and yield in a sub-humid tropical climate. Ann. Biol. Res. 2018, 9, 20-35.

46. Wallach, D.; Makowski, D.; Jones, J.; Brun, F. Evaluation, analysis, parameterization, and applications. In Working with Dynamic Crop Models, 1st ed.; Academic Press: San Diego, CA, USA, 2014; pp. 345-406.

47. Loague, K.; Green, R.E. Statistical and graphical methods for evaluating solute transport models: Overview and application. J. Contam. Hydrol. 1991, 7, 51-73. [CrossRef]

48. Ong, C.; Monteith, J. Response of pearl millet to light and temperature. Field Crops Res. 1985, 11, 141-160. [CrossRef]

49. Adnan, A.A.; Jibrin, J.M.; Abdulrahman, B.L.; Shaibu, A.S.; Garba, I.I. CERES-Maize model for determining the optimum planting dates of early maturing maize varieties in Northern Nigeria. Front. Plant Sci. 2017, 8, 1118. [CrossRef]

50. Lana, M.A.; Eulenstein, F.; Schlindwein, S.; Guevara, E.; Meira, S.; Wurbs, A.; Sieber, S.; Svoboda, N.; Bonatti, M. Regionalization of climate scenarios impacts on maize production and the role of cultivar and planting date as an adaptation strategy. Reg. Environ. Chang. 2016, 16, 1319-1331. [CrossRef]

51. Cooksey, B. The comprehensive africa agriculture development programme (CAADP) and agricultural policies in Tanzania: Going with or against the grain? In Future Agricultures; Sera: Heinsberg, Germany, 2013.

52. Allen, M.R.; Ingram, W.J. Constraints on future changes in climate and the hydrologic cycle. Nature 2002, 419, 228. [CrossRef]

53. Wright, J.P.; Posner, J.L.; Doll, J.D. The effect of tied ridge cultivation on the yield of maize and a maize cowpea relay in the gambia. Exp. Agric. 1991, 27, 269-279. [CrossRef]

54. Belay, A.; Gebrekidan, H.; Uloro, Y. Effect of tied ridges on grain yield response of Maize (Zea mays L.) to application of crop residue and residual $\mathrm{N}$ and $\mathrm{P}$ on two soil types at Alemaya, Ethiopia. S. Afr. J. Plant Soil 1998, 15, 123-129. [CrossRef]

55. Bayu, W.; Rethman, N.F.G.; Hammes, P.S. Effects of tied-ridge, nitrogen fertilizer and cultivar on the yield and nitrogen use efficiency of sorghum in semi-arid Ethiopia. Arch. Agron. Soil Sci. 2012, 58, 547-560. [CrossRef] 
56. Kassie, M.; Jaleta, M.; Shiferaw, B.; Mmbando, F.; Mekuria, M. Adoption of interrelated sustainable agricultural practices in smallholder systems: Evidence from rural Tanzania. Technol. Forecast. Soc. Change 2013, 80, 525-540. [CrossRef]

57. Cameron, A.; Derlagen, C.; Pauw, K. Options for Reducing Fertilizer Prices for Smallholder Farmers in Tanzania; FAO: Rome, Italy, 2019. [CrossRef]

58. Tebaldi, C.; Knutti, R. The use of the multi-model ensemble in probabilistic climate projections. In Philosophical Transactions of the Royal Society A: Mathematical, Physical and Engineering Sciences; The Royal Society: London, UK, 2007. [CrossRef]

(C) 2019 by the authors. Licensee MDPI, Basel, Switzerland. This article is an open access article distributed under the terms and conditions of the Creative Commons Attribution (CC BY) license (http://creativecommons.org/licenses/by/4.0/). 